\title{
Trade Union Influence in the Czech Republic since 1989
}

\author{
MARTIN MYANT* \\ University of the West of Scotland, Paisley
}

\begin{abstract}
Trade unions in the Czech Republic have experienced a steady decline in membership and, albeit less markedly, in bargaining coverage since the early 1990s, but much less decline in political influence. An assessment of the extent of their overall ability to influence society's development requires a division into three spheres: business, employment relations, and the state budget. Strength in one sphere is found to influence strength in others. The development of collective bargaining in workplaces and at the sectoral level took shape relatively early. Forms of political influence developed more gradually, by a learning process, to include a combination of participation in tripartite structures, organising mass protest demonstrations and lobbying MPs and ministers. The relative weights of these elements, and their effectiveness, have varied with different governments and balances of power in parliament.
\end{abstract}

Keywords: Czech Republic, trade unions, labour relations, tripartism

Sociologický časopis/Czech Sociological Review, 2010, Vol. 46, No. 6: 889-911

\section{Introduction}

The aim of this paper is to assess the influence of trade unions on post-1989 development in the Czech Republic. The central questions are whether their activities have made a difference to what has happened and, if so, how they have wielded an influence. That means looking at their activities and methods in relation to a number of different spheres. There are various simple measures, most obviously union membership and collective bargaining coverage, but they are not adequate for a full assessment. Union influence is more varied and complex, both in terms of what is influenced and of the methods used. A central argument is that influence may increase in some spheres while it declines in others. It depends on strategies, contexts, learning processes, and the activities of other actors. This makes trade union influence much more difficult to follow than that of other organisations representing particular interests or opinions.

The method used to assess union influence aims to unpick this complexity and to show how developments in one sphere of activity strengthen or weaken unions' influence in other spheres of activity. The article starts by outlining broad trends in union membership, the first proxy for influence, and then characterises the spheres of activity that unions can influence. This is followed by an assessment

\footnotetext{
* Direct all correspondence to: Martin Myant, Business School, University of the West of Scotland, Paisley PA1 2BE, UK, e-mail: martin.myant@uws.ac.uk.
}

(C) Sociologický ústav AV ČR, v.v.i., Praha 2010 
of the effects of the impact of union activities at the workplace level, through collective bargaining, and at the national political level. This latter area of influence underwent a process of change and evolution, partly as circumstances changed but also as unions learned and perfected the means of wielding influence. It is therefore best followed by a historical account of key 'incidents'.

The data used are derived predominantly from published union sources, with results broadly confirmed from interviews with officials of unions affiliated to the two main union centres and in a number of unaffiliated unions in the period from December 2009 to April 2010, ${ }^{1}$ and from unpublished membership data. The conclusion is that, while membership and influence in many workplaces has declined, unions have perfected methods for influencing national political development, primarily on issues of particular relevance to workplace employment relations but also as part of a broad support for what they see as a 'European' social model. ${ }^{2}$ Their influence depends on persuading political parties and MPs and it is therefore impossible to identify changes that did, or did not, occur because of trade unions' activity alone. They have also developed an informed voice on economic, social, and labour-relations themes that helps, at least potentially, to enhance the level of political debate, albeit, again, without leading to directly identifiable results.

\section{Trade union membership decline}

The bulk of Czech union members have been organised in unions affiliated to the Czech-Moravian Confederation of Trade Unions (Českomoravská konfederace odborových svazů - ČMKOS) which developed from transformation of the official unions of the communist period, inheriting substantial property and a mass membership base [Myant 1993]. Membership declined rapidly from 4.3 million in 1990 to 1.7 million in mid-1997, and to 471244 in 2009. The much smaller Association of Independent Trade Unions (Asociace samostatných odborů - ASO), formed in 1995 and uniting unions dissatisfied in very different ways with the ČMKOS, does not ask its affiliates for, let alone publish, membership data. ${ }^{3}$ There

\footnotetext{
${ }^{1}$ This was part of the European Trade Union Institute for Research (ETUI) project on mapping trade unions in the New Member States of the European Union. The full report on Czech trade unions is published as Myant [2010].

2 The inverted commas are appropriate because, although the EU did insist on some specific pieces of legislation and on some general principles that pointed to concern over social issues, it produced no full and comprehensive social model that all countries were required to adhere to. Trade unions were attracted to, and used the European label to describe, the commitments to welfare provision and employment protection that had developed in older EU member countries and that went beyond the conditions for EU membership [cf. Myant and Drahokoupil 2010: 91-92].

${ }^{3}$ For membership in the tripartite RHSD, referred to below, a union confederation was formally required to have 150000 members in affiliated unions. However, this was not a
} 
are also other, small and independent unions. Union density therefore cannot be calculated accurately, but probably fell from $80 \%$ to $33 \%$ of the employed labour force by 1997.

The figure cannot be calculated with precision partly because of uncertainty over the exact level of union membership, with ASO-affiliates and independent unions frequently providing no data, and partly because unions generally retained pensioners as members and these were often not counted separately. The number of pensioners varied enormously between unions, but often exceeded $20 \%$ of total membership. A reasonable estimate is that, by 2009, union density, meaning the number of members of all unions as a percentage of the employed labour force, had fallen to about 10\%, a figure significantly below the average in Western Europe.

Bargaining coverage also declined, albeit less dramatically. Agreements reached for groups of employees naturally applied to those who were not union members as much as to those who were. Bargaining was conducted at the sectoral level, between unions and employers' organisations covering, for example, textile or motor vehicle production, and at the enterprise level. The coverage of sectoral agreements varied with the ability and willingness of employers' organisations to negotiate. Data for ČMKOS-affiliated unions only show coverage of sectoral agreements declining through the mid-1990s to reach a low point in 1998, when only $11 \%$ of employees were covered. The level rose to $24 \%$ in 2009 [ČMKOS 2010b: 28]. The difference was due partly to growth following government use of a legal power to extend the coverage of sectoral agreements to include employers that were not party to the negotiations. This was important in construction and the textile industry. However, sectoral-level agreements were often very general and it is unclear how far they were enforced where enterprise-level union organisations were weak or non-existent.

Bargaining at the enterprise level was more important for setting pay, conditions, and often a range of further material benefits. ČMKOS estimates show $80 \%$ of employees were covered by such agreements in 1991-1993 [ČMKOS 2010a: 64-65]. Coverage of its own affiliates had fallen to 29\% in 2009 [ČMKOS 2010b: 28]. Including unions not affiliated to ČMKOS, total bargaining coverage can be estimated at somewhat over $30 \%$.

Comparisons across East-Central Europe show similar trends in both membership and bargaining coverage [Lawrence and Ishikawa 2005]. Explanations for declining membership have focused on structural changes in the economy unfavourable to union organisation [Bohle and Greskovits 2006] and on the legacy of the communist past, put most forcefully in Ost's writing on Poland [Ost 2007; also Crowley 2004]. Differences between countries, with unions in the Czech Republic

legal requirement and ASO was never asked, and never volunteered, to provide evidence of membership. There is no serious doubt that its membership was well below that level by 2010 [cf. Myant 2010]. 
appearing slightly more successful in terms of membership numbers than those in Poland and Hungary, but less successful than those in Slovenia, should then relate to differences in the nature of structural changes, in those legacies from the past, and in the structures and strategies that emerged from 1990 [cf. Avdagic 2005].

Structural change is most easily measured by shifting employment between broad sectors and the disappearance of established enterprises. In fact, changes were wider and deeper than broad figures would suggest, including new organisational structures for public administration, a total transformation of retailing with new owners and new workplaces, and substantial changes across industry and construction. As a general rule, where change was greatest, union membership fell most rapidly.

This can be illustrated from the experience of ČMKOS-affiliated unions, using their membership figures. The Firefighters' union had 6570 members in 2009 compared with 6602 in 1993. There had been a growth in the workforce and no major reorganisation of workplaces. At the other extreme, the union organising retail trade declined from 394909 members in 1990 to 136805 in 1993 and to 9751 in 2009, a quarter of which were pensioners, and most of the remainder worked in cooperative shops that had survived without major changes from the communist period. This sector had undergone sweeping changes and become dominated by foreign-owned outlets in which the union had very few members. However, there were also steady membership declines even where employment decline or reorganisation were much less pronounced: the union for schools had about onesixth of its 1993 membership by 2009 and that for health and social care had lost about three-quarters of its members. Evidently, other factors were also at work.

However, continuity in workplaces was important for retaining core union strength. This applied in some parts of important traditional sectors of industry, meaning heavy industry, mining, engineering, and motor vehicle production. The last of these in particular, as will be argued, had implications for establishing a wider union voice in employment relations and even for maintaining a voice in national politics. This may have been one factor helping Czech unions relative to those in neighbouring countries where modern manufacturing was more dependent on completely new inward investment.

Nevertheless, the extent of decline even where organisational changes were small points to the possible importance of other factors which could relate to legacies of the communist past, when unions had been 'transmission belts', never opposing the political leadership. ${ }^{4}$ Thus, union leaders and activists frequently refer to a general hostility from the media and much of the population towards ideas that could be associated with the political left. This could be consistent

\footnotetext{
4 The limited activities and centralised control of trade unions before 1989 can be followed from publications of the time [e.g. Richter and Kouřil 1970; Kupka 1974]. For a more recent account, see Stasek [2005].
} 
with opinion survey findings which frequently show only around one-third of the population expressing some degree of trust in unions, a figure significantly below those for the police, the army, and the media. The level was even lower in 1991, at 28\% [IVVM 1995], suggesting that many individuals may have been members in that early period only through inertia and that trust in unions may have increased even as membership fell.

An image of unions as part of the past may also be encouraged by a continued emphasis in many workplace organisations on providing social and recreational facilities and individual benefits to members. This had been their most visible activity in the communist period. A common view within unions was that such activities were important for retaining members, and especially older ones. It was often cited as the only basis for the existence of many workplace organisations. Nevertheless, it was also often cited as discouraging potentially younger recruits to whom unions could reportedly appear as 'a hobby club for employees coming up to retirement' [Unger 2006: 4].

However, probably the principal negative effect from the communist period was one that cannot be measured even approximately. The period of repression and acquiescence meant that there was no live tradition of militancy or of fighting for employees' rights against recalcitrant employers. The significance of this can be illustrated by comparison with the development of Western European union movements, and also Central European before the communist period.

This has been characterised [Crouch 1993] as a progression through unregulated conflict in workplaces, followed by more regularised collective bargaining as both sides learned to respect each other's strength and to see the benefits of reaching agreement without unnecessary conflict. Grass-roots militancy, and occasional unregulated conflict, continued to warn employers and governments of the unions' potential strength and also to foster a new generation of union activists. Czech unions, following the break imposed by state socialism, had lost touch with that starting point and strikes and other militant actions remained largely exceptional events. The absence of that heritage, it can be postulated, represented a major weakening factor for trade unions, leading to fewer committed individuals who could step forward to take the risk of setting up new organisations in new workplaces. This was particularly important in the context of structural changes in the economy and of the organisational structure of unions that developed after 1989.

The important point in relation to unions' organisation was that the former, highly-centralised structure was split up with basic organisations gaining most of the authority, holding the membership lists and retaining most of the membership dues. This had two negative consequences in the context of structural change in the economy. The first was that it was very difficult to establish organisations in new workplaces, as unions started, by definition, with zero membership. The second was that it was difficult to maintain organisations, as employment and hence membership in a workplace declined. One of the most frequently reported 
reasons for the decline of an organisation, repeated across unions' publications, was that as officials retired they were often hard to replace. The ultimate consequence was a possible loss of all members in that workplace. This organisational structure therefore contributed to a particularly rapid membership decline in the face of economic changes.

As part of their strategy for building a new identity distinct from the communist past, Czech trade unions set out to follow 'European' methods of collective bargaining in workplaces and to seek agreement and consensus with governments while also generally representing and defending the interests of the weakest in society. In practical terms that meant going beyond the immediate interests and concerns of union members in workplaces to include concern with a wide range of economic, employment-relations, and social policies. It meant trying to influence government decisions within those spheres. How far this was possible and the methods that could be used varied across these spheres. The implications of this are taken up in the following sections after a presentation of the different spheres of development that unions could hope to influence.

\section{Spheres of union influence}

The complexity of unions' influence is best unravelled by a division into three spheres of activity, business, employment relations, and the state budget. These are relevant both in setting the framework in which unions operate and as areas in which unions can try to influence outcomes. The important point is that outcomes in one sphere can also affect unions' ability to wield influence in another.

The business sphere covers profit-seeking activity, including private and state-owned businesses. It was dominated in the 1990s by large enterprises privatised into domestic ownership. They effectively collapsed at the end of the decade and their place was increasingly taken by foreign-owned companies, reaching $42 \%$ of industrial employment and $54 \%$ of value added by 2006 (calculated from the Czech Statistical Office, 2009, Table 16-85). These and other structural changes could have a major social impact and also, as indicated, an influence on trade union activity and membership. However, this was a sphere in which unions were largely passive bystanders.

The employment relations sphere is taken to cover wage determination and employee-employer relations in the workplace. Unions' most obvious influence is through bargaining with employers, but employment law set by parliament is also important to employee protection in work and to the environment for collective bargaining and is therefore also a matter of very direct interest. Much of the

\footnotetext{
${ }^{5}$ See http://www.czso.cz/csu/2009edicniplan.nsf/t/DD0030C725/\$File/00010916A08.xls (retrieved 1 November 2010).
} 
possible legislation carries minimal direct implications for state spending and this has meant that governments are under less pressure than in other spheres to disrupt any consensus that may exist between unions and employers' organisations.

This, then, was a very visible sphere of union influence and also the sphere in which there were the most obvious successes. Moreover, by strengthening the position of employees relative to employers and by producing results that presumably helped to maintain and recruit members, this enhanced unions' ability to wield influence in other spheres.

The state budget sphere covers the raising of revenues and areas of policy requiring state spending. It is of most direct concern to unions representing public-sector employees. It also links to the unions' general aim of defending the weakest in society, which implies support for redistributive policies. Those two concerns can come together around support both for state-run public services and for a degree of progressiveness in the tax system. Unions could influence this only by influencing government decisions and this became an arena for well-publicised actions. Although having little direct impact on actual policy decisions, these activities may have made some difference to the overall political climate in the country and hence to parliamentary election outcomes.

The following sections show how unions attempted to influence the three spheres and how far success in one sphere strengthened their hand in others.

\section{Collective bargaining}

The foundation of trade union activity was workplace collective bargaining which could be expected to lead to better conditions for employees than the legal minimum and to higher pay levels than if wages were set by employers alone. These benefits were assumed on the union side to be a major reason for individuals joining, and that was periodically confirmed by survey evidence (including the most substantial survey, which has not been repeated on a similar scale, by Waddington and Pollert [1997]). This rarely involved serious conflict and, at least from 1993, employers in state-owned or newly-privatised enterprises generally conceded pay rises slightly above the inflation rate.

Employers in established enterprises had good reason not to take an antiunion stand: unions were already well-established from the past; employers could afford the pay rises demanded; they had no conception of an alternative human relations strategy and they welcomed union passivity over privatisation plans and union support in giving employers a voice through the tripartite structures referred to below. In turn, the need to avoid identification with the communist past ruled out what could be characterised as a 'radical-oppositional' approach [Hyman 2001] from union organisations, with its likely associated rhetoric about working class solidarity and struggle. The aim was always agreement, backed by 
rhetoric about the benefits of social peace and reconcilability of social interests. As a result, there were practically no strikes over pay and this relaxed approach continued through the 1990s and into the next decade.

The lack of militancy in general, and over pay conditions in particular, can be illustrated by figures on all forms of protest actions from 1997 to 2004 recorded by $\mathrm{KOVO}$, the largest $\mathrm{C}^{\mathrm{MKOS}}$ affiliate representing engineering, electronics, and metal production [Myant 2007: 339]. The biggest were political demonstrations, discussed below. There were only eight very short protest strikes and three strikes of any significant length. None of these related to a collective agreement, to union recognition, or to victimisation. A few protest meetings and strike threats did relate to the first of these and one related to a US firm's anti-union attitude. The issues behind protests were usually linked to the financial collapse of enterprises privatised into Czech ownership and to their failure to pay wages during the crisis years of 1999 and 2000.

Unions were naturally keen to argue that collective bargaining brought benefits for members, but there is no systematic study making possible a quantification of such an effect. Unions' own data was frequently used to show comparisons between conditions where organisations could sign collective agreements and where they could not: the former generally enjoyed substantially higher wages and a range of further benefits in kind. A more systematic study by KOVO showed pay slightly above the sectoral average where agreements were signed (rising to almost $5 \%$ in 2005) and considerably below the average where union organisations existed but signed no collective agreement [Souček 2006]. Although indicative of a possible positive impact - of successful bargaining if not of union membership as such - any firm conclusion would depend on eliminating other possible reasons for higher pay in some enterprises, such as skill levels or the economic success of the firm. The fact remains that it was frequently impossible to convince employees in new work places that unions would bring them benefits. That may have been an accurate perception or it may have reflected ignorance of what unions could achieve.

Incoming foreign owners were a central part of structural changes. Where they bought established enterprises there was often continuity in unions' organisations and bargaining. Where they established new, greenfield plants, there were more reports of victimisation and intimidation to discourage unionisation, notably in electronics and even more frequently in retailing. ${ }^{6}$

Again, a major barrier to recruitment there appeared to be doubts that a union could better the pay levels on offer, which were generally significantly above

\footnotetext{
${ }^{6}$ For example, as reported by a union representative in a large electronics firm, 'people are scared', although this was tempered with 'but I have to say that I have not come across one case of somebody being bullied out of trade-union membership' [Mariel 2005: 1]. Other union reports referred to employers adopting a 'correct' attitude [e.g. Pacák 2005: 1] or taking unions for granted from the start [Přibyl 2005: 1].
} 
those in domestically-owned firms: lack of interest from younger employees was reported across all sectors (e.g. from a textile plant, 'the young don't take much interest, even though we have lots of benefits' [Pekarková 2005]). In the case of the new retail outlets, where unions could find a foothold they learned to proceed very cautiously, often using links with unions in the company's home country and reassuring employers that they were not a threat and then hoping gradually to strengthen their base. It is therefore likely that in many, if not the bulk, of new workplaces direct union influence was small. Indirect influence, especially through political actions to influence labour law, may have been considerable.

Organisational continuity gave the best chance of a strong union organisation. A particularly important one was the Škoda car manufacturer, a well-established company from the communist period that was taken over by Volkswagen in 1991. It continued with employment at around 20000 and the core workforce was still predominantly unionised in 2007. From 1993 onwards there was hard bargaining prior to the signing of annual collective agreements that then served as the pace setter for other enterprises.

There was no serious question of Volkswagen taking a strongly anti-union stand in view of the union's established position, the company's practice in Germany, concerns from German unions at the implications of a low-wage economy in East-Central Europe, and the affordability of wage demands. This, then, gave the establishment of collective bargaining in the Czech Republic a firm base and Škoda was a major factor in maintaining its continuity into the new millennium. Rather exceptionally, the union organisation also backed up its bargaining with threats of strike action in 2005 and by actually staging a strike in 2007. Despite union efforts to publicise 'the strike victory' as an example for others to follow [Stanislav Tomášek cited in Benešová 2005], there was no similar action in other enterprises on either occasion.

Nevertheless, the pay levels achieved were significantly above the average for the engineering industry and the willingness to take action was a warning to other employers of what could happen. The union organisation in the newly-established TPCA plant producing cars under the Toyota, Citroën and Peugeot labels, albeit with only $10 \%$ of employees organised, set out to match Škoda pay and conditions. In 2007 it came close, also successfully negotiating an array of further benefits publicised as equivalent to another 13\% of pay levels [Jančok 2007: 1, 4]. It is thus reasonable to assume that union action in Skoda led to higher pay there and in other industrial plants. It also, it is suggested in a following section, may have had a positive effect on unions' political voice at the national level.

This section has shown that, although there were some differences between periods, collective bargaining and workplace activities took a fairly definitive shape quite early on. Political influence, followed in subsequent sections, underwent a more complex process of evolution. It was partly dependent on strength from collective bargaining, which helped to secure the membership base and the organisational structures of national unions. However, political influence also de- 
pended on unions learning how to make use of that organisational strength in the political sphere, and that evolved over time. This is analysed in the following sections through a historical approach following key incidents that helped to shape and change its forms.

\section{Forming tripartite structures (1990)}

From the start, the main union confederation emphasised that they would not be linked to any particular political party. That was partly a reaction to the past links to the Communist Party, from which they wanted a firm and decisive break, partly an inevitable decision made in an early period when parties were yet to take shape, and partly a continuing pragmatic choice in view of the diversity of political views within the membership.

Nevertheless, ČMKOS has been identified by its opponents, in ASO, in other independent unions, and on the right of the political spectrum, as close to the Social Democrats. Some of its leading figures have been that party's parliamentary representatives. There is no doubting substantial common ground, in the broad conception of a 'European' social model and on many individual policy issues. There have also been some important policy differences, in the period when the Social Democrats dominated the government. However, the most important point for present purposes is that trade unions' political influence is not tied to one party, either in terms of how union thinking on policies develops or in terms of how influence is wielded. Unions have developed methods of influencing politics that are more complex and not dependent purely on which party holds power.

The great early hope for political involvement was seen in tripartite structures, modelled on experience in some western European countries and on the framework adopted by the ILO [Myant, Slocock and Smith 2000]. These were a common feature of post-communist countries, usually from the early 1990s, and one author even refers to 'transformational corporatism' as a new form of governance [Iankova 2002]. Others have referred instead to 'illusory corporatism' [Ost 2000]. Comparisons across Eastern and Central Europe show roles varying with specific national conditions [cf. Avdagic 2005]. Ost was therefore right that the existence of tripartite bodies says little about their actual impact, but over-generalises when characterising them as bodies used 'to rubber stamp and legitimise neo-liberal policies' [Ost 2000: 507]. In the Czech Republic they were neither irrelevant nor were they a central feature of the emerging political system. Their role evolved so that they became one part of a policy-making process.

Commitment to tripartism in the Czech Republic came first from unions in early 1990 and found a ready response from government members. Some were naturally sympathetic to consultation with representatives of social interests. Others were more naturally hostile, but feared social unrest during painful economic changes and therefore supported what Wiesenthal [1996] described as 'pre-emp- 
tive' corporatism, at least as a temporary form. This led to the creation of the tripartite Council for Economic and Social Accord (Rada hospodářské a sociální dohody, RHSD) in October 1990. Employers' representation was largely a token until, and to some extent even after, major enterprises were privatised. However, the employers' presence gave the body, and hence unions, greater legitimacy and ensured that employers would start off with a view of unions as allies in their commitment to a mechanism allowing access to the centre of power.

The RHSD never played a role in such central issues of economic reform as privatisation: in this early period unions effectively vacated the business sphere as an arena of political involvement. The first, and greatest, success was agreement in December 1990 on changes to the Labour Code, producing a framework that continued to provide substantial protection and apparently somewhat better conditions from the unions' point of view than in other countries in East-Central Europe [Avdagic 2005]. That success can be attributed to the trade unions' unity around one centre, to their potential strength, to their ability and determination to put forward proposals in this area above all others, and to the social-democratic thinking of the government partners with whom they negotiated. There was also some militant rhetoric, with threats of a general strike if demands were not met, but that probably exaggerated their real strength.

The agreement was significant in the first place for what it contained. It set minimal standards and conditions for all employees and provided a legal basis for collective bargaining, including powers for the government to extend sectoral agreements to employers that were not part of the employers' federation. It gave employees rights to information on a firm's performance, a right to consultation prior to dismissals, and, following some confused negotiations, failed to provide a full framework on strike action. Political strikes, defended symbolically after their role in the 'velvet revolution' of 1989 were, by default, legal [Myant 1993: 66-68]. It is a measure of unions' continuing influence that no subsequent government felt able to return to this issue and set clearer limits on the right to strike.

The agreement was also significant for the status it continued to give to legal processes in settling individual employment issues. The stated objective of unions and government at the time was to move from a situation in which laws defined what was allowed to one of greater liberalisation in which collective agreements could become more important. In practice, the legal minimum continued to be an important protection for employees and unions were heavily dependent on lawyers for fighting cases which they could often win. This strengthened the position of the confederation partly because it provided a network of lawyers' offices, used by individual unions, and partly because it created a need for a political voice to oppose changes that would weaken protection for employees. Thus, despite the decentralising trend after 1989, Czech unions were led back towards dependence on the political influence of a strong confederation.

It should be added that the Labour Code underwent frequent revisions in subsequent years, but always with union involvement in discussions, as indicat- 
ed in the following sections. The effect was to expand the full document, until by 2009 it ran to 396 paragraphs and 60000 words. Changes led to some liberalisation of employment relations, allowing for greater flexibility in work patterns, and to more recognition of specific conditions in particular occupations. However, the trade union side remained satisfied that they had ensured basic guarantees for employees' wage levels, for health and safety conditions, for maximum working hours, for holiday entitlements, and against dismissal without good cause [ČMKOS 2010b: 17].

EU accession, and the lengthy negotiations that preceded it, brought some changes, but most were relatively minor. The EU served primarily as an example that the union side could quote when opposing changes that would reduce employee protection and rights to information and consultation that already existed in Czech law. Among the more important EU-inspired changes was an anti-discrimination law that was finally passed in 2009, only after the EU had threatened substantial financial sanctions if this part of the accession terms were not honoured. Generally, however, agreement over employment law was to prove less difficult than other issues that would divide trade unions and government.

Indeed, and finally, the agreement reached in 1990 was also significant for showing both sides that consultation and negotiation could bring results. That set the scene for an attempt to expand the role of tripartite bodies closer to that of a neo-corporatist model.

\section{The 'General Agreement' (1991)}

A 'General Agreement' was signed by members of the RHSD on 28 January 1991 committing unions to support impending economic reforms and committing the government to prevent an excessive decline in living standards. The broad pact effectively ended when the government indicated that it could not guarantee the previously agreed level of wage indexation. Unions tried to protest, but there was no groundswell of militancy [cf. Myant 1993: 68-72]. It is worth emphasising more generally that the apparently slow growth in wages in the following years was not a result of a grand compromise involving unions, employers, and government. It could better be seen as reflecting the limits of union strength [cf. Boeri and Terrell 2002].

Thus, the RHSD failed as an arena for a kind of global collective bargain, as in a neo-corporatist model. It became no more than a consultative body through which the government could ascertain the views of key social partners and listen to them if it so wished: final decisions were taken by the government and parliament. There were even doubts on the union side as to whether they were achieving anything by continuing within these structures, but the implicit conclusion was that they lost nothing by participating as long as they also developed other parallel activities. Annual General Agreements were signed up to 1994, but by 
then had become so general as to have little significance. The union side had no interest in reviving the practice in later years.

Nevertheless, participation in the RHSD was judged to confer two important benefits. The first was that, under the Labour Code, the government was obliged to consult on all relevant legislation with social partners, meaning members of the RHSD, before they went before parliament. Comments might not be respected, but the advanced warning gave an opportunity to seek allies and unions could also be well-prepared when speaking directly to government representatives they met through the RHSD. The second advantage was that participation in the RHSD gave unions a status and legitimacy that could help in dealing with any public body or private company. The next stage was to learn how to use those advantages.

\section{Beyond and without the tripartite (1993-1997)}

The clarification and narrowing of the RHSD's role, and fears of a possible antiunion agenda from the new government from 1993, led ČMKOS to seek new and different forms of political involvement. This coincided with a shift in government priorities. After the important decisions on privatisation had been taken, debate moved to public services. ČMKOS took the initiative in campaigning against a government plan for pension reform which would reduce benefits and raise the retirement age. Pressure through the RHSD had proved fruitless. Unions thereby demonstrated that commitments to protecting the weakest in society were more than just rhetoric, that they were prepared to take a lead ahead of political parties, and that they recognised the need for new forms of activity if they were to wield influence on the budget sphere as well as maintaining their position in the employment relations sphere.

Their membership base and hence financial strength were essential to the pressure they could mount. Thanks to their small expert teams and contacts with union centres in neighbouring European countries, they could develop an alternative to the government's proposal - the unions talked of a fully-funded scheme rather than continued dependence on the state budget - with which union leaders could argue on television and other public platforms. The membership base and organisational structure also enabled them to gain 630000 signatures for a petition and 50000 participants in a street demonstration, which was followed by a fifteen-minute general strike on 21 December 1994 involving about one-tenth of the labour force, with others staging other forms of protest. The aim was to influence public, and hence political, opinion and thereby to influence how MPs would vote. It was not seen on the union side as part of bargaining or negotiations with government or as reasserting a more prominent formal role for unions through tripartite bodies or other channels [Myant, Slocock and Smith 2000: 730-731]. Thus it was more modest than the political use of the strike weapon 
in some Western European countries [cf. Hamann and Kelly 2004], reflecting an implicit acceptance that neo-corporatism was not a realistic target.

The government won the crucial vote in parliament, but unions had won over enough MPs to make it a close result. That showed the potential for combining expertise, public protest, formal approaches, and lobbying of MPs across a wide political spectrum. This last element was to prove particularly promising, as Czech parliaments were finely balanced from 1996 to 2010 and discipline was not rigid in any party.

There were possible alternative strategies. There were no vocal calls for exclusive links to one party, but a few unions argued for a more militant approach, meaning more political strike action. None of this was immediately relevant. The government under Václav Klaus responded to the union's success in wielding some influence by downgrading the tripartite structure so that it could not discuss economic issues. That was to prove only a temporary interlude. The unions' profile, but not immediately their direct influence on politics, rose again as the divisions in the government increased in 1997.

The mechanism of their revival was complex [cf. Myant, Slocock and Smith 2000]. One element was a strike by railway workers in February 1997 that forced a government capitulation over restructuring plans and pay. The tripartite structure was revived shortly afterwards in its original form. However, this was not a result of some new global bargain. The railway workers union actually left ČMKOS and joined ASO, accusing the former of insufficient militancy. Klaus's interest in a formal tripartite structure is best interpreted as an attempt to pre-empt a more general militancy from unions. He had no interest in any further concessions and nothing important was agreed through the revived RHSD. However, with the economy entering a renewed depression and the government appearing divided and incompetent, unions were in a belligerent mood and staged a demonstration in Prague on 8 November, to which 100000 came to hear calls for a new government. Opinion survey evidence suggests that it had a substantial impact, with 79\% saying the government should listen to the demonstrators' views [IVVM 1997].

This demonstrated the unions' ability to mobilise supporters, as they had in 1994, but it left open important questions about how that support could be used. Calling for a change of government was close to calling for support for the Social Democrats, expected to emerge as the largest party in forthcoming elections. ČMKOS did not take that final step and it is impossible to estimate how far their actions may have affected electoral preferences.

Staging a major demonstration pointed to the question of what to do if it was ignored: again there were some calls for a general strike, but even raising the stakes with more vigorous forms of protests need not force a government to concede. That potential dilemma was resolved when the government did resign, reflecting divisions within its own ranks as its popularity fell, to be replaced by an interim, non-party government, and then by a minority Social Democrat government after the elections in June 1998. 


\section{Influencing the Social Democrat-dominated governments (1998-2006)}

The period after 1998 saw a consolidation and realignment of unions' methods of political influence. The key point was the willingness of the government to listen to the union voice, reinforced by the EU support for social dialogue and involving social partners in policy making, but the scope that opened up had to be exploited by active steps from the union side. The result was to entrench some new practices and structures that survived after the creation of a right-wing government in 2006.

Unions systematised their approach in three respects:

The first was in the process of commenting on new legislation. ČMKOS received advanced notification of all new proposals relating to economic, social, and employment policies. These were discussed within its Legislative Council, in 2010 a 25-member body bringing together affiliated unions' lawyers. It was able to use its policy expertise to prepare coherent comments and to take part in discussion with relevant ministers. Employers' organisations were similarly wellplaced to comment, and some NGOs were in time given the same opportunity, but ČMKOS was in the position to give the most informed input on the widest range of policy issues. The number of pieces of legislation discussed ranged up to an annual level of 323, reached in 2007.

This obviously depended on ČMKOS and individual unions maintaining significant apparatuses and bodies of expertise. Their ability to do this could have been reduced by declining membership and hence weaker finances, but the impact of that was tempered by income from inherited property ${ }^{7}$ and by giving priority to activities that enabled them to assess and comment on legislation.

The second was the systematisation of lobbying in parliament. ČMKOS had an employee follow all parliamentary business and various union leaders established contacts across much of the political spectrum, albeit frequently with a better hearing from the Social Democrats and the Communists. The ability to influence MPs from other parties was often crucial in view of the small majorities in many parliamentary votes.

The third was influence through the formal tripartite structures. The RHSD developed a substantial apparatus of commissions on individual sectors and themes, totalling 19 in 2010, and individual unions often also had formal repre-

\footnotetext{
${ }_{7}$ Czechoslovak, and subsequently Czech, trade unions were able to retain the property built up by unions under state socialism [Myant 2010]. Much of this was lost or squandered during the 1990s. Some individual unions were left with next to nothing, but a number were rich enough to own offices and hotels and to earn a steady income that could support their own employees and activities. This inherited property led to some very bitter conflicts between, and within, unions. For present purposes it is important as a factor that enabled unions to survive financially, often quite comfortably, even as membership declined, and hence to retain the means to influence politics.
} 
sentation in consultative bodies within ministries. This supplemented and often also enabled direct contacts to ministers and their deputies.

These methods of influencing decisions obviously depended on the willingness of government to listen. The formalisation of representation at several levels made this more likely. When that failed there was scope for public protest actions but, while methods of influencing decisions were becoming more systematic, the power to stage large-scale protests was threatened by the declining membership base. Thus, the successes in influencing policy depended on unpublicised work of experts and union leaders, but they could go largely unnoticed by actual or prospective members and therefore probably had little direct impact on union membership numbers. Public protests inevitably came when other methods had failed and never led to major changes in policy decisions. Nevertheless, it was the public protests that raised the unions' profile and that therefore presumably made it easier to hold existing, and to recruit new, members.

The period up to parliamentary elections in June 2006 saw ČMKOS working reasonably happily with the government. A very crude numerical indicator of the new balance of influence was that the minimum wage, having fallen from $53 \%$ of the average wage in 1991 to $23 \%$ in 1998, rose back to $35 \%$ of the average wage in mid-2006. However, influence beyond the employment relations sphere was still limited and dependent on unions' ability to prove that they represented a strong body of public opinion. When they came into serious conflict with the government, they were unable to make headway. This can be followed around their ability to wield influence in the three spheres referred to above.

Agreement was easiest in discussions over revisions to the Labour Code, an issue opened up partly by the need for changes in the light of EU accession in 2004. The government actually proposed only relatively minor changes, but an alternative view came first from right-wing politicians and then from some employers' representatives who took up the same themes, arguing for the right to dismiss without providing a reason and resenting laws that set limits to working time and overtime unless unions agreed to their prolongation and to laws that gave unions significant rights over the enforcement of health and safety rules. Union leaders consistently viewed the Labour Code as an issue on which they could expect strong backing from members. That in turn impressed those employers who feared provoking unnecessary conflict with unions.

It was noteworthy that Vratislav Kulhánek of the Škoda car manufacturer, the locus of the most obvious union workplace strength, and Vice President of the Union of Industry and Transport, firmly distanced himself from the anti-union rhetoric in his organisation's statements at a major public debate with trade union and government representatives. ${ }^{8}$ From his point of view, it can be hypoth-

8 This is the report of a public debate on the theme of the kind of Labour Code needed to ensure economic growth and social cohesion held on 27 October 2005 and involving Vratislav Kulhánek of the Škoda car manufacturer, Zdeněk Škromach, Deputy Prime Minister 
esised, liberalisation of labour law would achieve nothing of substance, while risking worsening workplace relations and possibly also risking worsening relations with unions in Germany where labour protection was at least as good as in the Czech Republic. It was a firm perception from the union side that big multinational companies which recognised and worked with unions in their home countries were among the most likely to treat unions with respect, even if some explicit persuasion from unions in the firms' home country was sometimes necessary. The ability to reach agreement with such employers during negotiations in the RHSD greatly strengthened the unions' hand in arguing against reductions in employee protection in the Labour Code. Nevertheless, just to be sure of a satisfactory parliamentary vote, unions still mobilised a joint demonstration of both centres, attended by 25-30 000 supporters, on 26 November 2005, backing the government's proposals as they were presented to parliament.

The period after 1998 led to an unusually high level of union interest in the fate of the business sphere. The economic crisis in 1998 - with the effective collapse of the major enterprises privatised into Czech ownership, delays in payment of wages to an estimated 53000 employees and unemployment rising to 9.4\% in 1999 from $3.5 \%$ in 1996 - led to frequent protest actions from basic organisations, typically with calls for the government to step in to save jobs. At the national level unions - citing the risk of unregulated conflict - emphasised the urgency of seeking remedies. The few bitter disputes that did take place, over closure of mines in Northern Bohemia in 1999, did not win union backing and protests did not develop into any kind of direct threat to the government. Nevertheless, they strengthened the unions' hand by acting as a reminder of a possible threat to social peace if the demands of employees were ignored.

The threat of possible labour unrest was probably one factor persuading the government of the need to seek a systematic solution, but union thinking made little difference to the form of that solution. The policy was for slimming down failing enterprises and selling viable parts to foreign companies, alongside systematic encouragement of inward direct investment [Myant 2003: Chapter 10]. Thus, unemployment was kept in check by encouraging changes in the structure of the business sphere that, it could be argued, were unfavourable to union activity.

The unions' approach to the business sphere meant that they could find common ground with some employers, notably mining companies over the benefits of continued open-cast mining, despite complaints over its environmental impact. It can be added that the union voice with the government, through tripartite structures and through other forms of lobbying, was a powerful one on issues related to unemployment and regional development. They were therefore useful allies to that part of business and this, alongside unions' willingness to

and Minister of Labour and Social Affairs, Milan Štěch, Chair of ČMKOS and member of the Senate, and Petr Šimerka, Deputy Minister of Labour and Social Affairs. See http:// www.fontes-rerum.cz/soubory/download/zakonik.pdf (retrieved 1 November 2010). 
oppose what they saw as pointless strike action, in turn could have weakened any possible inclination among large employers to pursue an anti-union agenda. Thus, involvement in policies for the business sphere, while changing very little directly, could have contributed to better relations with some employers, and hence to some strengthening of unions' ability to influence government.

This was no help to unions when they came into conflict with the government over changes in the state-budget sphere. This became a major issue partly because the budget deficit rose after the depressed economic conditions of the later 1990s. There was a gathering consensus across much of the political spectrum, including dominant media and academic opinion, that taxes as well as spending were too high. A further factor was impending EU accession, which brought criticisms from Brussels of the size of the budget deficit (for a discussion of pressures on the government, see Myant [2008: 119-124]).

The fiscal reform negotiated in the government, from 2002 a coalition of Social Democrats and parties to their right, involved cuts in benefits and in some taxes. ČMKOS demonstrated that it had the resources and expertise to produce a coherent alternative that would also have reduced the deficit [Fassmann et al. 2004], arguing for smaller reductions in taxes on enterprises, higher taxes on top incomes, and no cuts in state benefits.

There was no prospect of gaining influence across the political spectrum on this issue. Parties to the right of the government were even more committed to tax and spending cuts. Lobbying could bear fruit only among 'left' Social Democrats, and that was not enough to shift the government. In line with its established practice, ČMKOS then tried to impress the government through public protests. They claimed participation of 20000 at a demonstration on 13 September 2003, intending to influence the parliamentary debate that was about to begin. The practical impact was small, but the issue anyway subsided, as a good economic performance improved the budget situation and reduced the need for spending cuts.

The outcome of protests demonstrated the very limited scope for political influence by these means even under a Social Democrat government. Union action was at most a warning that reform in the neo-liberal direction would not be painless for a Social Democrat government.

\section{After the 2006 elections}

The parliamentary elections in 2006 led to an unstable period, with parliament at first equally divided between left and right. A right-wing government held power until it was followed, after defeat in a vote of no confidence in March 2009, by a non-party government backed across most of the political spectrum and after the elections in 2010 by a right-wing government with a solid parliamentary majority. Unions were active in trying to influence political events, but there was, at least to 2010, no major development in their methods. Changes were rather in 
the weight and effectiveness of the different methods that had been developed in the past.

The right-wing government set about pursuing a vigorous neo-liberal agen$\mathrm{da}$, including cuts in welfare benefits, charges for health care, and changes in the tax system to reduce its progressiveness. There was an initial intention to block the new Labour Code, but this rather faded when unions and employers themselves settled on some minor changes to the previously agreed form. More revisions were proposed in later months, but were again strongly opposed by unions and ended with the government's fall. The focus of government policies therefore remained the state budget sphere, especially its welfare and redistributive elements.

The union response was led from ČMKOS, while other unions, at most, followed behind. The first step was production of a comprehensive and detailed critical analysis of the proposals [ČMKOS 2007] which gave the unions a strong position in developing an intellectual opposition to the government. The analysis was distributed to all political parties, but only the Social Democrats and Communists expressed any interest. Government parties were unimpressed and seeking consultation through the RHSD produced no significant result beyond confirming that there was disagreement.

With the established methods of influencing and lobbying at a dead end, the next stage was a conference of union representatives, the first such event since 1989, which was attended by 1700 delegates, on 19 May 2007. Perhaps surprisingly, it was not a public event, reflecting fears that that could distort the discussion, and media coverage was limited. It therefore served to publicise the ČMKOS analysis primarily within affiliated unions, while providing a forum for deciding on protest action. The decision was for a public demonstration on 23 June which was attended by an estimated 35000 participants. It was a substantial display of opinion, representing a greater proportion of union members than had been prepared to take part in the analogous demonstration in 1994. However, it failed to alter the government's policy and appeared not to influence discussion within the coalition government. Consideration was then given to a short general strike, albeit conceived only as a demonstration reminding politicians of the trade unions' support, rather than as a step towards formal negotiations with the government.

Despite the apparent failure to alter government policy, trade union actions could have had an important impact on the general political climate - showing opposition to a neo-liberal direction and thereby increasing the likelihood of a different outcome to the next parliamentary elections - and on trade unions' standing among potential supporters. The active membership of ČMKOS affiliates enthusiastically took up the case of opposition to the new government's policies. There was no expression, either in public or through the main union structures, of significant doubts or reservations in relation either to the ČMKOS position or to the benefits or legitimacy of taking an apparently political stand. 
The fall of the right-wing government, coinciding with the uncertainty created by the effects of the world economic crisis from 2008, led to a much more fluid political situation and a new government that appeared more willing to listen to outside opinions. This situation changed radically after the formation of a right-wing government with a solid majority after the parliamentary elections in June 2010. This can be expected to reduce the unions' ability to influence political decisions, but it may increase their standing as a centre of opposition to the government. The full implications for relations with the government, with employers and with political parties, and hence for trade union methods and effectiveness, remain to be seen.

\section{Conclusion}

In the 20 years since 1989 Czech trade unions, or at least those affiliated to ČMKOS, have kept the same broad aims and the same broad approach to both workplace and political involvement. However, the means by which they influenced developments and the success with which they did so changed as a result both of changed circumstances and of an evolution of practices. This can be summarised in the following points:

First, membership depends on workplace organisations which have undergone substantial decline. The reasons for this include structural changes in the economy, various sources of a negative or unattractive image for unions, and a union organisational structure that hampers successful reactions to these problems.

Second, declining workplace strength has limited unions' ability to influence workplace conditions by collective bargaining, but they retain substantial power in this sphere thanks also to their ability to influence labour law. Where workplace organisation has remained strong, it is hypothesised, the threat of possible workplace conflict encourages employers not to provoke conflict with unions at the national level over labour legislation. Workplace organisation is also an essential base for national organisation and hence political influence.

Third, methods of wielding political influence developed through the 1990s and had taken broadly definitive form by the end of that decade. Working through tripartite structures and through lobbying proved effective on issues of labour legislation, but was often only a means of flagging up disagreements over major issues of state spending. Much of this was conducted away from the public eye and therefore made little direct difference to retaining and gaining members.

Finally, when persuasion failed, unions turned to forms of public protest with the aim of shifting opinion, in the first instance in the existing parliament, but also with a view to influencing the outcome of future elections. The ability to stage public demonstrations was weakened by declining membership, but not to the same extent: the remaining membership was presumably more commit- 
ted and more willing to raise its voice. These actions backed up quieter forms of persuasion on labour-legislation issues, but made little immediate difference in other policy areas. They nevertheless always helped to raise the unions' public profile and, in so far as that improved their image among part of the population, could also have helped them to gain members and to strengthen their position in workplaces. Thus, a process of learning how to wield influence meant that declining membership was not automatically associated with declining influence.

Martin Myant is a professor in the Business School, University of the West of Scotland, Paisley, UK. He has previously published on economic and political development in Central and Eastern Europe, particularly the former Czechoslovakia and the Czech Republic. His latest book, written with Jan Drahokoupil of the University of Mannheim, is Transition Economies: Political Economy in Russia, Eastern Europe, and Central Asia. (2010, Hoboken, NJ: Wiley).

\section{References}

Avdagic, Sabina. 2005. 'State-labour Relations in East Central Europe: Explaining Variations in Union Effectiveness.' Socio-Economic Review 3: 25-53.

Benešová, Jana. 2005. 'Živá voda pro Středočechy - Proč ve Škodě Auto odbory vyhrály.' (New Life for Central Bohemia - Why the Trade Unions Won in the Škoda Car Manufacturer) Kovák 22, April 2005. Retrieved 1 November 2010 (http://www.oskovo.cz/kovak/2005/k14_25.htm).

Boeri, Tito and Katherine Terrell. 2002. 'Institutional Determinants of Labor Reallocation in Transition.' Journal of Economic Perspectives 16: 51-76.

Bohle, Dorothee and Bela Greskovits. 2006. 'Capitalism without Compromise: Strong Business and Weak Labor in East Europe's New Transnational Industries.' Studies in Comparative International Development 41: 3-25.

ČMKOS. 2007. Analýza dopadů reformy veřejných financí stran ODS-KDU/ČSL-SZ. (Analysis of the Impact of the Reform of Public Finances of the Political Parties ODS, KDU-ČSL and SZ) Prague: ČMKOS.

ČMKOS. 2010a. Cesty, kř̌zovoatky, střety nových odborů: 20 let hájime práva zaměstnanců. (Roads, Crossroads and Conflicts Encountered by the New Trade Unions: We Have Defended the Rights of Employees for 20 Years) Prague: ČMKOS.

ČMKOS. 2010b. Zpráva Rady ČMKOS pro V. sjezd ČMKOS. (Report of the ČMKOS Council to the 5th Congress) Prague: ČMKOS.

Crouch, Colin. 1993. Industrial Relations and European State Traditions. Oxford: Clarendon Press.

Crowley, Stephen. 2004. 'Explaining Labor Weakness in Post-communist Europe: Historical Legacies and Comparative Perspective.' East European Politics and Societies 18: 394-429.

Czech Statistical Office. 2009. Statistical Yearbook of the Czech Republic. Prague: Český statistický úrad. Retrieved 1 November 2010 (http://www.czso.cz/csu/2009edicniplan.nsf/p/0001-09). 
Fassmann, Martin, Vladimír Pelc and Růžena Vintrová. 2004. Mýty, lži a pověry českých reforem veřejných financí. (Myths, Lies and Superstition about the Czech Public Finance Reforms) Prague: Pohledy.

Hamann, Kerstin and John Kelly. 2004. 'Unions as Political Actors: A Recipe for Revitalisation?' Pp. 93-116 in Varieties of Unionism: Strategies for Union Revitalization in a Globalizing Economy, edited by Carola Frege and John Kelly. Oxford: Oxford University Press.

Hyman, Richard. 2001. Understanding European Trade Unionism. London: Sage.

Iankova, Elena. 2002. Eastern European Capitalism in the Making. Cambridge: Cambridge University Press.

IVVM (Institut pro výzkum veřejného mínění). 1995. 'Důvěra občanů v některé instituce.' (The Trust of Citizens in Various Institutions) Research Report No. 9510. Prague: IVVM.

IVVM (Institut pro výzkumy veřejného mínění). 1997. ‘K názorům na listopadovou demonstraci ČMKOS.' (Opinions on the ČMKOS November Demonstration) Research Report No. 9712. Prague: IVVM.

Jančok, Miroslav. 2007. 'Nejen slyší, ale také činí.' (It Doesn't Only Hear, But Also Acts) Kovák 18, 10 May. Retrieved 1 November 2010 (http://www.oskovo.cz/kovak/2007/k18_27.htm).

Kupka, Jaroslav. 1974. Postavení a úloha odborũ za socialismu. (The Position and Role of Trade Unions under Socialism) Prague: Práce.

Lawrence, Sophia and Junko Ishikawa. 2005. 'Social Dialogue Indicators: Trade Union Membership and Collective Bargaining Coverage: Statistical Concepts, Methods and Findings.' Working Paper No. 59. Geneva: ILO, Policy Integration Department.

Mariel, Jaroslav. 2005. 'Dokud je z čeho brát.' (As Long as There's Something to Take From) Kovák 1, 14 January. Retrieved 1 November 2010 (http://www.oskovo.cz/kovak/2005/k01_25.htm).

Myant, Martin. 1993. 'Czech and Slovak Trade Unions.' Journal of Communist Studies 9: 60-84.

Myant, Martin. 2003. The Rise and Fall of Czech Capitalism. Cheltenham: Edward Elgar.

Myant, Martin. 2007. 'Trade Unions in the Czech Republic.' Pp. 335-346 in Trade Union Revitalisation: Trends and Prospects in 34 Countries, edited by Craig Phelan. Oxford: Peter Lang.

Myant, Martin. 2008. 'Les gouvernements sociaux-démocrates et la variété de capitalisme en République tchèque.' Critique internationale 39: 111-138.

Myant, Martin. 2010. Trade Unions in the Czech Republic. Brussels: European Union Trade Institute.

Myant, Martin and Jan Drahokoupil. 2010. Transition Economies: Political Economy in Russia, Eastern Europe, and Central Asia. Hoboken, NJ: Wiley.

Myant, Martin, Brian Slocock and Simon Smith. 2000. 'Tripartism in the Czech and Slovak Republics.' Europe-Asia Studies 52: 723-739.

Ost, David. 2000. 'Illusory Corporatism in Eastern Europe: Neoliberal Tripartism and Postcommunist Class Identities.' Politics E Society 28: 503-530.

Ost, David. 2007. 'Trade Union Revitalisation in Poland: Trends and Prospects.' Pp. 303-317 in Trade Union Revitalisation: Trends and Prospects in 34 Countries, edited by Craig Phelan. Oxford: Peter Lang.

Pacák, Roman. 2005. 'Liberecké nebe a dudy.' (The Good and the Bad in Liberec) Kovák 16, 6 May. Retrieved 1 November 2010 (http://www.oskovo.cz/kovak/2005/k16_25.htm). 
Pekarková, Ivana. 2005. 'STAP Vilémov u Šluknova.' (The STAP Company in Vilémov u Šluknova) TOK noviny 6.

Přibyl, Ivan. 2005. 'Olomoucká bílá vrána.' (The Rare Bird in Olomouc) Kovák 28, 2 September. Retrieved 1 November 2010 (http://www.oskovo.cz/kovak/2005/k28_25.htm).

Richter, Jiří and Karel Kouřil. 1970. Postavení a úloha odbori za socialismu. (The Position and Role of Trade Unions under Socialism) Prague: Práce.

Souček, Jaroslav. 2006. ‘Kampaň na podporu kolektivního vyjednávání podnikových kolektivních smluv na rok 2007' (The Campaign in Support of Negotiating Enterprise Collective Agreements for 2007). Kovák 27, 25 August. Retrieved 1 November 2010 (http://www.oskovo.cz/kovak/2006/k27_26.htm).

Stasek, Frantisek. 2005. 'Employee Relations in the Czech Republic - Past, Present and Future.' Employee Relations 27: 581-591.

Unger, Rudolf. 2006. 'Nelitují života pro odbory.' (They Have No Regrets over a Life for Trade Unions) Kovák 20, 2 June. Retrieved 1 November 2010 (http://www.oskovo.cz/kovak/2006/k20_26.htm).

Waddington, Jeremy and Anna Pollert. 1997. Odbory v České republice. (Trade Unions in the Czech Republic) Prague: ČMKOS.

Wiesenthal, Helmut. 1996. 'Organized Interests in Contemporary East Central Europe: Theoretical Perspectives and Tentative Hypotheses.' Pp. 40-58 in Parliaments and Organized Interests: The Second Steps, edited by Attila Ágh and Gabriella Ilonszki. Budapest: Hungarian Center for Democracy Studies Foundation. 